\title{
IDENTIFIKASI KARAKTERISTIK ALAT PENCERNAAN KELELAWAR PTEROPUS ALECTO DI SULAWESI BAGIAN UTARA
}

\author{
Leo. K. Pendong* J.F. Umboh**, M. Imbar*, C.A. Rahasia* \\ Fakultas Peternakan Universitas Sam Ratulangi, 95115
}

\begin{abstract}
ABSTRAK
Studi ini bertujuan mengungkap ketergolongan kelelawar Pteropus alecto (paniki yaki), berdasarkan jenis pakan dan sistem pencernaannya. Penelitian ini menggunakan metode deskriptif eksploratif. Data-data primer, meliputi: materi kelelawar, identifikasi karakterisasi morfologi organ/alat pencernaan (laboratoris). Data-data sekunder diperoleh dari daerah asal sampel, meliputi: informasi habitat dan jenis pakan. Hasil penelitian menunjukkan, ciri-ciri umum dari kelelawar Pteropus alecto, baik jantan maupun betina, warnanya hitam pekat, berbulu di seluruh bagian tubuh, tidak mempunyai ekor, bentuk muka menyerupai seekor anjing, memiliki cakar yang tajam melengkung pada jempol tangan, juga pada kedua jari-jari kakinya, untuk menggelantung. P. alecto yang diamati memiliki panjang tubuh rata-rata 16,4 $\mathrm{cm}\left(\right.$ () dan 22,5 $\mathrm{cm}\left({ }^{\lambda}\right)$, dengan bobot badan jantan $\pm 719,87 \mathrm{gr}$, lebih berat dibanding betina (526,5 gr). Profil organ-organ cerna, yaitu: susunan formula gigi: $I=2 / 2 ; C=1 / 1$; $P m=2 / 2 ; \quad M=3 / 4, \quad$ dengan jumlah gigi keseluruhan 34. Organ saluran pencernaannya diduga lebih besar, lebih panjang, dan lebih berat, dari pada kelelawar jenis pemakan buah lainnya, dimana panjang lambung $\pm 8,45 \mathrm{~cm}$ (ठ) - 8,04 (), panjang usus halus $\pm 289,3 \mathrm{~cm}$ () $-302,42 \mathrm{~cm}\left({ }^{\Uparrow}\right)$, dan usus besar $\pm 24,13$ $\mathrm{cm}($ (q) $-27,3 \mathrm{~cm}($ ( ). Beberapa jenis pakan yang kebanyakan dimakan oleh kelelawar $P$. alecto, yaitu buah papaya (Carica papaya), pisang (Musa paradisica), Mangga (Mangifera indica), Sirsak (Annona muricata), Jambu (Psidium guajava) dan bunga kelapa (Cocos nucifera). Kesimpulan. Kelelawar Pteropus alecto memliki susunan organ-organ cerna
\end{abstract}

*Alumni Fakultas Peternakan

**Jurusan Nutrisi dan Makanan Ternak yang umumnya sama seperti hewan monogastrik lainnya, tetapi tidak memiliki sekum dan tidak memiliki ruang cerna fermentatif, dimana pakan utamanya adalah buaha-buahan, sehingga dapat dikategorikan sebagai hewan monogastrik herbivora frugivora (non pseudo-ruminanisa).

Kata kunci :Pteropus alecto, organ pencernaan, jenis pakan

\section{ABSTRACT}

\section{CHARACTERISTICS IDENTIFY OF THE DIGESTIVE ORGANS OF BAT (PTEROPUS ALECTO) IN NORTHERN} SULAWESI. The study aimed to classify Pteropus alecto (Black flying foxes=paniki yaki), based on the type of feed and the digestive system. A Descriptive explorative method was used in this study. The primary data, consist of animals sample, and of laboratory identification of the shapes physical morphology and size of digestive organs. The secondary data was taken by collecting the information from bat origin region, or its habitat. The results showed, the general characteristics of bat (Pteropus alecto), both male and female were performed a hairy color black in all parts of the body (except in the wings), it has no tail, the face shape resembles a dog or fox, has sharp curved claws on thumb, also on both toes, for hanging. The body length of the observed $P$. alecto were $\pm 16.4 \mathrm{~cm}(q)$ and $\pm 22.5 \mathrm{~cm}\left({ }^{\lambda}\right)$, with the body weight was $\pm 719,87 \mathrm{~g}$ on male, heavier than females $( \pm 526.5 \mathrm{~g})$. The profiles gastrointestinal organs of bat, viz: the teeth, stomach, intestine, and colon. Yhe teeth formula, were $I=2 / 2 ; \mathrm{C}=1 / 1 ; P m=2 / 2 ; M=$ $3 / 4$, the number of overall teeth were 34 . The digestive tract organs of bat $(P$. alecto) were suspected bigger, longer, and heavier, than 
other frugivore bat types, where the length of the stomach were $\pm 8.45 \mathrm{~cm}\left({ }^{\Uparrow}\right)$ and 8.04 (ㅇ), the length of the small intestine were \pm 289.3 $\mathrm{cm}\left(\right.$ $(+)$ and $302.42 \mathrm{~cm}\left({ }^{\Uparrow}\right)$, and the colon were $\pm 24.13 \mathrm{~cm}($ ( $)$ and $27.3 \mathrm{~cm}\left({ }^{\pi}\right)$. The mostly feed types being eaten by $P$. alecto, namely: papaya (Carica papaya), banana (Musa paradisica), mango (Mangifera indica), soursop (Annona muricata), guava (Psidium guajava) and coconut flower (Cocos nucifera) It is oncluded, bat (Pteropus alecto) has a digestive organs system which generally similar to other monogastric animals, but it has no cecum, and no space for fermentative digestion, and where it main feed is fruits, so it can be categorized as frugivores herbivores monogastric animal (non pseudo-ruminant).

Keywords: Pteropus alecto, feed type, digestive tract organs

\section{PENDAHULUAN}

Indonesia memiliki keragaman hayati melimpah, baik flora maupun fauna. Pulau Sulawesi yang sebagian besar wilayahnya termasuk dalam zona ekologi garis Wallace (Wallace line) menjadi rumah bagi flora dan fauna (biodiversity richness) nomor dua di dunia setelah Brazil.

Masyarakat Sulawesi Utara, lebih khusus masyarakat suku Minahasa dikenal sebagai konsumen berbagai jenis hewan baik domestik maupun hewan liar. Diantara beberapa jenis hewan liar yang sering dikonsumsi, kelelawar merupakan salah satu sumber daging yang paling disukai, bahkan menjadi salah satu "extreme culinary" di daerah ini.

Ada sekitar 62 spesis kelelawar, baik jenis dalam ukuran yang relatif besar, maupun sampai pada jenis yang terkecil di dunia, terdapat di Sulawesi (Whitten, et al., 1987; Heinrichs, et al., 1997). Salah satu spesis kelelawar yang memiliki ukuran tubuh lebih besar, yang hidup tersebar di beberapa habitat hutan hujan tropis di Sulawesi bagian Utara adalah rubah hitam terbang (Black flying fox)
Pteropus alecto. Spesis kelelawar ini pertama kali dijelaskan oleh Temminck (1837) dalam Wilson dan Reeder (2005) berdasarkan specimen yang diperoleh dari Manado, Sulawesi Utara. Spesis Pteropus alecto (Black flying fox, termasuk dalam famili Pteropodidae (Old World fruit bats = kelelawar buah dunia lama), genus Pteropus, dengan sub spesis Pteropus alecto alecto (Ten Pas, 2004; Myers et al., 2014). Jenis kelelawar inilah yang dikenal dalam sebutan lokal (Minahasa) paniki yaki.

Sampai sekarang ini, Informasi ilmiah, khususnya anatomi dan fisiologi pencernaannya, ternyata masih sangat kurang, bahkan belum diketahui secara jelas, "apakah kelelawar (paniki yaki) tergolong dalam hewan monogastrik karnivora, monogastrik omnivora, monogastrik herbivora ataukah karnivora?". Untuk itu, dilakukanlah studi/penelusuran ilmiah menyangkut karakteristik alat/organ-organ pencernaan, juga pengenalan terhadap jenis-jenis pakan alamiah yang biasa dikonsumsi, pada habitat di mana kelelawar (paniki yaki) ini hidup, dengan tujuan mengungkap ketergolongan kelelawar Pteropus alecto alecto (paniki yaki) berdasarkan jenis pakan dan sistem pencernaannya.

\section{MATERI DAN METODE PENELITIAN}

Penelitian ini dilakukan di wilayah Sulawesi bagian Utara sebagai sumber atau asal materi penelitian kelelawar Pteropus alecto (paniki yaki), dan pengamatan morfologi dan alat pencernaan kelelawar di Laboratorium Jurusan Nutrisi dan Makanan Ternak, Fakultas Peternakan Unsrat. Penelitian dilksanakan sejak bulan Agustus 2012 sampai dengan bulan Desember 2012.

\section{Materi Penelitian}

\section{- Hewan penelitian}


20 ekor (10 ekor jantan dan 10 ekor betina) kelelawar (Pteropus alecto), yang berasal dari berbagai daerah di Sulawesi bagian Utara, hasil tangkapan pemburu liar atau yang dijual di pasar-pasar tradisional, dijadikan obyek dalam penelitian.

\section{- Peralatan}

Peralatan yang digunakan yaitu: alat bedah (pisau bedah atau scalpel, gunting, gunting dengan penjepit), alat ukur berat (timbangan), alat ukur panjang, kantong sample, tali plastik, mistnett (jaring pukat), dan kamera digital.

\section{Metode}

Penelitian ini menggunakan metode observasi melalui koleksi, tabulasi data, menghitung rata-rata variabel yang diamati. Data yang diambil merupakan data primer dan data sekunder. Data primer diperoleh dari observasi langsung dan pengamatan langsung di laboratorium, sedangkan data sekunder diperoleh dari hasil informasi pemburu liar, masyarakat sekitar hutan, dan berbagai pihak yang terkait dengan kebutuhan penelitian ini.

\section{- Daerah Asal Sample dan Habitat}

Kelelawar yang dijadikan objek pengamatan, umumnya berasal dari daerah Taman Nasional Bogani Nani Wartabone dan sekitarnya, di mana di daerah ini merupakan salah satu habitat asli kelelawar tersebut dan masih banyak ditemukan kelelawar (Pteropus alecto), termasuk yang dijual di pasar-pasar tradisional.

\section{- Makanan}

Data jenis pakan, serta sumber pakan lainnya juga dikumpul informasinya dari para pemburu dan masyarakat yang bermukim dekat dengan habitat kelelawar Pteropus alecto, kemudian direlevansikan dengan sumber-sumber referensi ilmiah.

\section{- Karakteristik bentuk (morfologi)}

Morfologi hewan diperoleh dari pengamatan langsung terhadap penampilan fisik, melalui pengukuran panjang tubuh, muka, telinga, bentangan sayap, tungkai tangan, dan pengukuran berat hidup. Selanjutnya, dilakukan interpretasi dan deskripsi hasil penelitian.

\section{- Karakteristik}

organ/alat

\section{pencernaan}

Karakteristik organ pencernaan diperoleh dari pengamatan dan pengukuran panjang dan berat dari masing-masing segmen organ-organ/alat pencernaan, yaitu, gigi, lambung usus halus dan usus besar.

\section{Prosedur Penelitian}

20 (dua puluh) ekor kelelawar Pteropus alecto, terdiri dari : 10 (sepuluh) ekor jantan dan 10 (sepuluh) ekor betina, dibedah untuk pengamatan dan pengukuran. Objek pengamatan yang utama, meliputi: $a$ ) rongga mulut: susunan gigi, b) lambung: volume, struktur, dan bintil-bintil (papilla) pada masing-masing segmen, $c$ ) usus halus dan usus besar.

\section{Analisis Data}

Data hasil penelitian dianalisis secara deskriptif eksploratif dan statistik sederhana. Tabulasi data dan nilai rataan masing-masing variable, dianalisis dengan menggunakan persamaan (Walpole, et al., 1986)

$$
\bar{X}=\frac{\sum X}{n}
$$

di mana $: \bar{X}=$ rataan hasil pengukura; $n=$ jumlah hewan; $X=$ data hasil pengukuran

\section{HASIL DAN PEMBAHASAN}

\section{Habitat}

Habitat kelelawar Pteropus alecto yaitu di hutan primer Taman Nasional 
Bogani Nani Wartabone. Taman nasional ini merupakan kawasan peralihan geografi daerah Indomalayan di sebelah Barat dan Papua-Australia di sebelah Timur (Wallacea Area), memiliki luas 287.115 ha dan terletak di antara Kabupaten Bolaang Mongondow dan Kabupaten Gorontalo (Sulawesi bagian Utara). Taman Nasional Bogani Nani Wartabone memiliki sekitar 24 jenis hewan mamalia, salah satu di antaranya adalah kelelawar Pteropus alecto (BPKH-Dephut, 2007). Dapat dikatakan Taman Nasional ini merupakan habitat kelelawar Pteropus alecto, sumber asal kelelawar yang digunakan dalam penelitian ini.

\section{Karakteristik Bentuk}

Ciri-ciri umum dari kelelawar Pteropus alecto yang diamati, baik jantan maupun betina, warnanya hitam pekat, dan berbulu di seluruh bagian tubuh. Kelelawar ini tidak mempunyai ekor, telinganya kecil dan lancip, dan bentuk muka menyerupai seekor anjing. Hewan ini memiliki cakar jempol tangan yang tajam dan melengkung, juga kedua kaki dengan cakar jari-jarinya yang kuat, yang berfungsi untuk menggelantung.

\section{Penampilan Fisik Kelelawar}

Dari hasil pengamatan (tabel 1) mengindikasikan, bahwa antara kelelawar $P$. alecto jantan dan betina berbeda dalam bentuk fisik, dilihat dari berat hidup, panjang tubuh, dan lebar tubuh. $P$. alecto jantan memiliki berat hidup $\pm 719,87$ gr lebih berat dari berat hidup betina $( \pm 526,5$ gr).

Tabel 1. Rataan ukuran penampilan fisik kelelawar $P$. alecto jantan dan betina

\begin{tabular}{ccccccccc}
\hline \hline $\begin{array}{c}\text { Sample } \\
\text { Kelelawar }\end{array}$ & $\begin{array}{c}\text { Berat } \\
\text { hidup } \\
(\mathrm{gr})\end{array}$ & $\begin{array}{c}\text { Panjang } \\
\text { bentang } \\
\text { sayap } \\
(\mathrm{cm})\end{array}$ & $\begin{array}{c}\text { Panjang } \\
\text { kaki } \\
(\mathrm{cm})\end{array}$ & $\begin{array}{c}\text { Panjang } \\
\text { tubuh } \\
(\mathrm{cm})\end{array}$ & $\begin{array}{c}\text { Lebar } \\
\text { tubuh } \\
(\mathrm{cm})\end{array}$ & $\begin{array}{c}\text { Panjang } \\
\text { telinga } \\
(\mathrm{cm})\end{array}$ & $\begin{array}{c}\text { Panjang } \\
\text { siku } \\
\text { tangan } \\
(\mathrm{cm})\end{array}$ & $\begin{array}{c}\text { Panjang } \\
\text { muka }(\mathrm{cm})\end{array}$ \\
\hline \multirow{1}{*}{} & 719.8 & 112 & 12.1 & 22.5 & 9.2 & 3.1 & 17.1 & 8.0 \\
+ & 526.5 & 112 & 12.6 & 16.4 & 7.9 & 3.1 & 16.4 & 6.7 \\
\hline
\end{tabular}

\section{Morfologi Organ/alat Cerna Kelelawar}

\section{Ukuran Organ/Alat Pencernaan}

Profil organ-organ pencernaan dari spesis Pteropus alecto, baik jantan maupun betina memiliki karakteristik pencernaan yang diduga lebih besar, lebih panjang, dan lebih berat, dibanding kelelawar jenis pemakan buah lainnya. Neuweiler (2000) mengemukakan, panjang usus halus dari kelelawar frugivora, lima sampai sembilan kali panjang tubuh. Sementara, panjang tubuh kelelawar $P$. alecto yang diamati rata-rata $16,4 \mathrm{~cm}(q)$ dan 22,5 cm (ふ) (tabel 1), dengan panjang usus halus rata-rata $289,3 \mathrm{~cm}$ (q) dan $302,42 \mathrm{~cm}$ (ふ̋) (tabel 2), yang berarti panjamg usus halus sekitar 13 kali panjang tubuh. 
Tabel 2. Rataan ukuran organ/alat pencernaan kelelelawar P. alecto

\begin{tabular}{cccccccccc}
\hline \hline Sample & $\begin{array}{c}\text { Eesopagus } \\
(\mathrm{cm})\end{array}$ & $\begin{array}{c}\text { Panjang } \\
\text { lambung } \\
(\mathrm{cm})\end{array}$ & $\begin{array}{c}\text { Panjang } \\
\text { usus halus } \\
(\mathrm{cm})\end{array}$ & $\begin{array}{c}\text { Panjang } \\
\text { usus besar } \\
(\mathrm{cm})\end{array}$ & $\begin{array}{c}\text { Panjang } \\
\text { Alat cerna } \\
(3+4+5)(\mathrm{cm})\end{array}$ & $\begin{array}{c}\text { Diameter } \\
\text { lambung } \\
(\mathrm{cm})\end{array}$ & $\begin{array}{c}\text { Diameter } \\
\text { usus }(\mathrm{cm})\end{array}$ & $\begin{array}{c}\text { Berat } \\
\text { hati } \\
(\mathrm{gr})\end{array}$ & $\begin{array}{c}\text { Berat } \\
\text { usus } \\
(\mathrm{gr})\end{array}$ \\
\hline 1 & 2 & 3 & 4 & 5 & 6 & 7 & 9 \\
\hline 0 & 12,28 & 8,45 & 302,42 & 27,03 & 337,90 & 11,29 & 2,48 & 23,6 & 25,6 \\
+0 & 12,25 & 8,04 & 289,53 & 24,13 & 321,70 & 11,10 & 2,41 & 23,6 & 23,9 \\
\hline
\end{tabular}

\section{Gigi}

Jenis kelelawar ini memiliki gigi yang lebih luas diameternya serta relatif lebih datar untuk menggiling atau menghancurkan buah-buahan yang dimakan, memungkinkan kelelawar jenis ini untuk memeras dan bekerja bagai mesin pembuat juice (juicer) dan menelan buah tersebut yang sudah dalam bentuk juice (Gardner, 1977; Tedman and Hall 1985; Dempsy, 2004).

Formula gigi dari kelelawar $P$. alecto yang diamati: Insisicum $=2 / 2$; Caninum $=1 / 1 ; \quad$ Pre $\quad$ molaris $=2 / 2$; Molaris $=3 / 4$, dengan jumlah gigi keseluruhan $=34$ (gambar 2$)$. Neuwiler (2000) melaporkan formula gigi pada pteropus, sp. I: 2/2; C: 1/1; PM: 3/3 M: 2/3 $=36$, Gigi taring yang menonjol dan gigi molar merupakan bentuk yang bermodifikasi untuk tujuan memakan buah. Langit-langit memiliki undulanundulan melintang yang digunakan berinteraksi dengan lidah untuk menghancurkan makanan lunak.

\section{Lambung}

Hasil pengamatan menunjukkan, lambung kelelawar memiliki panjang berkisar $7-10 \mathrm{~cm}$, dengan rataan $8,45 \mathrm{~cm}$ (ふ) dan 8,04 (), berbentuk memanjang pada ujungnya yang berhubungan dengan usus halus. Dumont (1997) mengemukakan, bahwa lingkungan lambung dari kelelawar frugivora tampaknya lebih asam. Dijelaskan, bahwa kemungkinan meningkatnya keasaman saliva dari frugivora adalah agar pencernaan protein dapat dimaksimalkan, untuk mengimbangi kandungan rendah protein dalam buah-buahan dan juga terhadap lajunya pakan melalui saluran cerna pada kebanyakan kelelawar frugivora. Diduga, dengan $\mathrm{pH}$ rendah, baik saliva, maupun di dalam lambung frugivora, berfungsi sebagai pelindung terhadap mikro-organisme yang berpotensi membahayakan.

Dari hasil pengamatan yang dilakukan tidak ditemukan adanya konsentrasi-konsentrasi terjadinya fermentasi anaerob di sepanjang alat pencernaan, khususnya pada lambung atau pada usus besar. Dugaan paling masuk akal adalah bahwa lambung yang membesar, panjang dan kompleks, serta usus halus yang berbelit dan berkantongkantong (convoluted) pada kelelawar buah, memungkinkan tersedianya ruang dan areal permukaan yang dibutuhkan untuk pencernaan dan absorbsi nutrient dari volume makanan dalam bentuk cairan yang dikonsumsi.

\section{Usus halus dan usus besar}

Usus halus dan usus besar kelelawar dalam pengamatan tidak ditemukan adanya sekum seperti yang terdapat pada monogastrik lainnya. Melalui identifikasi bagian organ cerna, usus halus berukuran panjang rata-rata $289,3 \mathrm{~cm}$ (ㅇ) dan 302,42 cm $(\hat{0})$, sedangkan usus besar bentuknya agak lurus dan tidak berkantong, dengan ukuran panjang berkisar $24,13 \mathrm{~cm}$ (q) $27,3 \mathrm{~cm}\left(\partial^{\lambda}\right)$. Usus halus dan usus besar pada $P$. alecto tidak menunjukkan adanya perbedaan yang jelas dibandingkan dengan usus halus ternak non ruminansia, 
herbivora monogastrik ataupun karnivora lainnya.

Pada $P$. alecto volume makanan yang besar diproses dan melewati saluran pencernaan begitu cepatnya, dengan transit time berkisar antara 15-100 menit. Lambung spesies kelelawar buah $P$. alecto besar dan kompleks, usus halus panjang, dan berbentuk seperti berkantong-kantong (convoluted), tidak ada sekum, dan usus besarnya pendek dan hampir tidak bisa dibedakan dari usus kecil (Tedman and Hall 1985; Klite (1965) dalam Dempsy, 2004).

\section{Makanan}

Jenis tanaman atau buah yang merupakan makanan kelelawar $P$. alecto berdasarkan informasi yang diperoleh dari para pemburu kelelawar di daerah ini, yaitu buah papaya (Carica papaya), pisang (Musa paradisica), Mangga (Mangifera indica), Sirsak (Annona muricata), Jambu (Psidium guajava) dan bunga kelapa (Cocos nucifera). Dempsey (2004) mengemukakan, megachiroptera famili Pteropodidae merupakan kelelawar pengunjung tanaman dan makan buahbuahan dan sumber-sumber pakan dari bunga-bungaan (tepung sari bunga).

\section{KESIMPULAN}

- Kelelawar pemakan buah Pteropus alecto memliki susunan organ-organ cerna yang umumnya sama seperti dengan yang dimiliki hewan monogastrik lainnya, tetapi tidak memiliki sekum dan tidak memiliki ruang cerna fermentatif, dimana pakan utamanya adalah buah-buahan sehingga dapat dikategorikan sebagai hewan monogastrik herbivora frugivora (non pseudo-ruminanisa)

\section{DAFTAR PUSTAKA}

Balai Pemantapan Kawasan Hutan,

Departemen Kehutanan. 2007. Profil
Kawasan Konservasi Sulawesi Utara

Taman Nasional Bogani Nani

Wartabone.

Dempsy, J.L. 2004. Fruit Bats: Nutrition and dietary husbandry. Adapted (and updated) from Dempsey, J.L. 1998. Recent advances in fruit bat nutrition. $P p$. 354-360 in Fowler, M.E.and R.E. Miller (eds.). Zoo and Wild Animal Medicine: Current Therapy 4. W.B. Saunders Co., Philadelphia, PA. www.researchgate.net/...FRUIT_B ATS.../0f31753... (12 November 2014)

Dumont, E.R. 1997. Salivary pH and buffering capacity in frugivorous and insectivorous Bats. J. Mammalogy, Vol. 78, 4:1210-1219

http://www.bio.umass.edu/biology/ ../Dumont_1997_JournalofMamma logy... (6 November 2014)

Gardner, A. L. 1977. Feeding habits. Pp. 293-350 in Baker, R.J., J.K. Jones, Jr., and D.C. Carter (ed.). Biology of Bats of the New World Family Phyllostomatidae, Part II. Mus. Texas Tech. Univ. Spec. Publ.13.

Heinrichs., Scott., Zahnke, and Kirsty. 1997. The fruit bats of sulawesi. BATS Magazine Media \& Education, vol. 15, 3. 
http://www.batcon.org/.../resources/

media-edu../bats-mag.../bat article/...

(14 November 2014)

Klite, P.D. 1965. Intestinal bacterial flora and transit time of three neotropical bat species. J.Bacteriology 90:375379.

Myers, P., R. Espinosa, C.S. Parr, T. Jones, G.S. Hammond, and T.A. Dewey. 2014. The Animal Diversity Web (online).

http://animaldiversity.org.

November 2014)

Tedman, R.A. and L.S. Hall. 1985. The morphology of the gastrointestinal tract and food transit time in the fruit bats Pteropus alecto and P. poliocephalus Neuweiler. 2000. The Biology of Bats. Oxford University Press.

https://global.oup.com/academic/pro duct/biology-of-bats- (24 November 2014)

(megachiroptera). Australian Journal of Zoology, 33(5) 625 - 640. http://www.publish.csiro.au/paper/Z O9850625.htm (6 November 2014)

Ten Pas, D. 2004. "Pteropus alecto" (Online), Animal Diversity Web http://animaldiversity.ummz.umich.e du/accounts/Pteropus_alecto/ (5 November 2014)

Walpole, E., Ronald, H., Majers dan Raymon. 1986. Ilmu Peluang dan Statistik, ed.2, ITB, 1986.

Wilson, D.E. and DeeAnn M. Reeder (Editors). 2005. Mammal Species of the World. A Taxonomic and Geographic Reference $3^{\text {rd }}$ ed, Johns Hopkins University Press, 2,142 pp. http://www.departments.bucknell.ed u/biology/resources/msw3/...

(24 November 2014)

Whitten, A.J., G.S. Henderson, M. Mustafa. 1987. Ekologi Sulawesi. Gadjah Mada University Press. Yogyakarta. 